\title{
Student Perspective on Technology Enabled/Enhanced Active Learning in Educational: Rasch Measurement Model
}

\author{
Hassan. N. F, Puteh. S, Muhamad Sanusi. A \& Che Mohamad Zahid. N. H
}

\begin{abstract}
:
Nowadays, the industrial revolution 4.0 had given a great impact on education. An active environment which applied technology in education can developed multiple skills in students. Technology Enabled/Enhanced Active Learning (TEAL) is one of the active environments that used technology in education. TEAL is the combination of several active learning domains which enhances students' understanding of learning and built job-related skills. However, students have lack of knowledge in their field which led to increase in unemployment of students. Hence, TEAL can help students in perform their practical works to develop knowledge and skills in students. This pilot study was distributed survey question about create an active and effective environment using TEAL application among the engineering students. The survey is consisted of 141 items and was distributed to 40 respondents. This pilot study used Rasch Measurement Model for measuring the validity and reliability of survey questions. Winsteps software is used to check the functionality of the item in terms of (i) Reliability and separation of respondents - items; (ii) detect the polarity items of PTMEA CORR Value; (iii) the item fit based on MNSQ Value; and (iv) Determine the dependent items based on the standardized residual value measurement correlation. The final result 109 items is suitable to use for measurement of the real study in future work.
\end{abstract}

Keywords: (Technology Enabled/Enhanced Active Learning (TEAL); Rasch Measurement Model; Winsteps software)

\section{INTRODUCTION}

The formation of the fourth industrial revolution currently emphasizes to enhance the quality of graduates to become a professional worker with an advanced technology. In order to achieve that goal, educational institutions need to collaborate with industries to create Technology Enable/Enhanced Active Learning (TEAL) approached for helping students to learn technologies tools. This is important to give students the chance to develop their experience, to develop the skills and gain knowledge in technology user [1,2]. At the same time, students can train themselves how to learn and explore a concept learning which can improve their understanding in their fields, as they can be practiced that skill when working

Revised Manuscript Received on 14 September, 2019.

* Correspondence Author

Nur Farha Hassan*, FTVE, Universiti Tun Hussein Onn Malaysia, 86400 Parit Raja, Batu Pahat, Johor, Malaysia. Email: nurfarhahassan@gmail.com Saifullizam Puteh, FTVE, Universiti Tun Hussein Onn Malaysia, 86400 Parit Raja, Batu Pahat, Johor, Malaysia. Email: saifull@uthm.edu.my

Amanina Muhamad Sanusi, FTVE, Universiti Tun Hussein Onn Malaysia, 86400 Parit Raja, Batu Pahat, Johor, Malaysia. Email: nina_sanusi@yahoo.com

Nor Hartini Che Mohamad Zahid, FTVE, Universiti Tun Hussein Onn Malaysia, 86400 Parit Raja, Batu Pahat, Johor, Malaysia. Email: hartini zahid@gmail.com

in industries $[3,4]$. This is necessary to encourage students to venture into the digital technology industries in competing globally to achieve success [5,2]. Therefore, the rapid development of advanced technology is important to support the enhancement of the quality of product manufacturing in industry.

Thus, educational institutions have to provide TEAL approach to produce highly skilled workers, who have the ability and special skills to applied technologies. This technology learning is one of the educational institutions platforms in Malaysia to produce professional manpower, which have good in tech savvy, expert in handling technology, able to compete in work, ability to handle pressure at work, have high confidence and various employability skills [6,7]. This approach starts from build-up the flexible learning space to create an active activity to give opportunity for student. That can help students to explore by their own lesson about the contents of their subject by using effective pedagogy techniques to become quality graduates. The TEAL approach is about Teaching and Learning (TnL) process that uses technology to assist in producing active learning activities. This process focus on learning outcomes and not on technology equipment only, but to attract students' involvement in the learning process for gain knowledge, skill and experience in the engineering fields [8].

The purpose of this study was to conduct a test of validate and reliability of the instrument that had been developed using TEAL approach. According to $[9,10,11]$ state that the pilot study need to be conducted carefully to improve the quality of items, based on confidence in interpreting data. However, before pilot studies, instrument needs to undergo the validity of content and construct, face and language. This is important to see the recommendation from the experts for improving the items in questionnaire. Three conditions that need to be occupied when conducting a pilot study were; (i) Make sure respondent not involved in actual study; (ii) Given complete instrument to respondent and; (iii) Used simple terms that can clarity the meaning for each item easily. Rasch measurement model via Winsteps was used to analyze the data from the pilot study in this research. Referring to suggestion from [12,13] mention that Rasch Measurement Model is one of model that formed a result of considerations of each respondents and items ability; (i) Respondent who answer questionnaires and; (ii) Difficulty level of each item (Rasch, 1980; Yasin et al., 2015). 


\section{LITERATURE REVIEW}

\section{A. Technology Enabled/Enhanced Active Learning}

Technology Enabled/Enhanced Active Learning (TEAL) approach was one of strategies that create an active learning environment which consists of three combinations which were involving delivery of lesson content, simulation activities and hands on experiences of student to applied digital technology $[14,15,16,17]$. This learning approach is the core of formation smart classroom for using innovation technology that applied to create an active environment with variety of activity to ensure students more understand with their lesson [18,19,20,21,22]. The TEAL approach is pedagogical innovation established first at Massachusetts Institute of Technology (MIT) in 2001 by John Belcher to upgrade system teaching and learning (TnL) with active elements for make students is engage with their own lesson enjoyable [14,18,23].

This approach had been applied in a few of university from around the world to enhance the system of educational. That few universities such as National Chung Cheng University (CCU) in Taiwan on 2004, Indiana University South Bend (IUSB) in United States on 2010, North Carolina State University (NCSU) in United States on 2011 and Singapore University of Technology and Design (SUTD) in Singapore on 2013 were collaborating with MIT in apply TEAL approach $[24,25]$. This collaboration shows that this TEAL approach was needed to be practice at any educational institutions, to help student volunteer participation in their own learning for more understanding about what they learn in classroom. The TEAL approach involved the adaptation of new technologies to support contents of learning in applied effective pedagogical in creating an active environment for student [26,27,28,29].

\section{B. Technology Enable/Enhanced Active Learning Instrument Development}

In this study, the instrument known as the Technology Enabled/Enhanced Active Learning (TEAL) aimed to produce quality graduates which can understand clearly in their fields to applied technologies in practical work for gain their employability skill. The skills can prepare students to face the industries need, especially to perform their ability in technical work using digital technology, tools, equipment and machine that have in industry [30,31]. This TEAL instrument development is based on the previous finding from the qualitative phase. The domains was identified from previous studies, articles, journals, books and theories or models, while elements of the domains were from interview sessions and consensus agreement with experts. The questionnaire was developed based on the 5 domains of active learning:

(i) Online Learning is the application using websites of internet for get some materials and information that student's needs. This part is consisting of 11 elements and 36 items have developed;

(ii) Blended Learning is a combination of online and face to face learning approach that is used to support content and integrated learning activities in applied technology for produce an optimal and effective learning. This part is consisting of 8 elements and 24 items have developed;

(iii) Collaborative Learning is sharing idea in group work to give chance for students learn like real works in industries, where the company needs the employees who are able to communicate well and confident interact with people. This part is consisting of 8 elements and 24 items have developed;

(iv) Practical Learning is to train students to do experiment, that needs develop hands on skills using digital and electronic tool for improve their technical works. This part is consisting of 8 elements and 24 items have developed;

(v) Interactive Learning is the simulation and visualized concept to exposure and explain the learning content by using multimedia application, that for students to more understand about what they learn. This part is consisting of 11 elements and 33 items have developed.

But the pilot study conducts all the 141 item of 46 elements in one process directly. The item development is based on adaptation from previous studies to helping create questions from elements that obtained from the qualitative research. Then the questionnaire was validated by the experts in terms of content and construct, face and language to ensure the items was suitable to measure the research questions of this study $[32,33]$. Two experts in languages and four experts in contents and face of the active learning area were used in the validation.

\section{Methodology/Materials}

\section{A. Sample and Data Collection}

This study was a survey research conducted at the Department of Civil Engineering, University Tun Hussein Onn Malaysia (UTHM). A total of 40 students from final year students who take the Bachelor of civil engineering involved in this study. In this research, survey was considered as a pilot study; at first 60 set of questionnaires was distributed to the respondents but only 54 sets were given back and only 40 sets can be used for the pilot study. The balance of the questionnaire was rejected because the answer was not complete. The total of the questionnaire collected was enough to run the pilot study because according to $[34,35]$ the total of 30 respondents is sufficient for the analysis of external validity and reliability index. Process of data collection started when researcher makes a deal with dean of engineering faculty to allow the distribution of the survey to final year's students. Then, after getting the permission, researcher needs to deal with student representative for distribute survey to their classmates. Researcher was allowed to enter the classroom to explain the purpose of the study. Those strategies help researcher to collect data smoothly with monitoring the students answer the items. 


\section{B. Survey of Research and Data Analysis}

This instrument was developed based on the domains and elements of Technology Enabled/Enhanced Active Learning (TEAL), where the researches explore from documents analysis and interview from experts. The surveys consist of 5 domains, (i) Online Learning; (ii) Blended Learning; (iii) Collaborative Learning; (iv) Practical Learning and; (v) Interactive Learning. This survey consists of 141 items for 5 domains. The survey used Likert scale of five options to measure agreement from respondent. Either (1) strongly disagrees; (2) disagree; (3) not agree; (4) agree and; (5) strongly agree [9]. Then, data were analyzed by using Rasch Measurement Model via Winsteps software to validate and reliability the items use in [36]. To check the functionality of each item needs:

(i) Reliability and separation of respondents (person) and items.

(ii) Detect the polarity items of Point Measure Correlation (PTMEA CORR) Value.

(iii) The item fit based on MNSQ Value.

(iv) Determine the dependent items based on the

Standardized Residual Correlation Value measurement.

\section{RESUlts AND FindingS}

\section{A. The Content Validation}

After pilot study was conducted, researcher needs to check the validity of questionnaire to ensure the content of items was accurate to measure the research questions in this study. Checking by experts was one of the validity in these studies which have three processes, first is content and constructs validation is needed to ensure the content of item is referring with the construct or elements that find in previous process. Each of items should have ability to measuring instrument that successfully to elicited respondent for represent the whole domain of online learning, blended learning, collaborative learning, practical learning and interactive learning to cover all finding. The items should be able to measure the needs to clarity of content constructs of study.

Secondly is face validation was to ensure the surface of questionnaire to identify that item level is for bachelor, easy to understanding and the design clearly to help respondent answer smoothly. That face validation was one of important part to prepare the good instrument because the surface or design that use in survey is to attract respondent to answer it. Then, the thirdly was language validation to ensure the questions used short word and simple term to make it easy to answer. The language term was important to declare the meaning of each question can measure constructs or elements in this study. In this study six experts were involved to checking the instruments. The comment and recommendation from experts needs to repair for improve the validity of instrument.

\section{B. Reliability and Separation Index}

Referring to [37] the best acceptable Cronbach Alpha $(\alpha)$ values is between of 0.71 to 0.99 . According to Table I show

that interpretation of Cronbach Alpha score. In this pilot study, the result of Cronbach Alpha value is 0.99. That mean, instrument is very good and effective level of consistency to use in actual research

Table I: Interpretation of Cronbach Alpha-Score

\begin{tabular}{|c|c|}
\hline $\begin{array}{c}\text { Cronbach Alpha } \\
\text { Score } \\
\end{array}$ & Reliability \\
\hline $0.8-1.0$ & $\begin{array}{c}\text { Very good and effective level of } \\
\text { consistency }\end{array}$ \\
\hline $0.7-0.8$ & Good and acceptable \\
\hline $0.6-0.7$ & Acceptable \\
\hline$<0.6$ & Item need to be repaired \\
\hline$<0.5$ & Items need to be dropped \\
\hline
\end{tabular}

Then, to check the functionality of each item needs to follow the requirement of Rasch measurement model which is show in Table II. According to [36] the correct procedure of pilot test is important to measure the validity and reliability of item that development in research.

Table II: Criteria for Examining Outliers

\begin{tabular}{|c|l|c|}
\hline No. & \multicolumn{1}{|c|}{ Criteria for Examining } & Requirement \\
\hline 1. & Reliability person- items & $0.67 \leq$ Reliability $\geq 0.80$ \\
\hline 2. & Separation person- items & $\geq 2.00$ or $\approx 2.00$ \\
\hline 3. & $\begin{array}{l}\text { Point Measure Correlation } \\
\text { (PTMEA CORR) value }\end{array}$ & $\begin{array}{c}\text { PTMEA CORR } \neq \text { negative } \\
(-)\end{array}$ \\
\hline 4. & $\begin{array}{l}\text { Outfit mean square } \\
\text { (MNSQ)value }\end{array}$ & $0.6<$ MNSQ $>1.4$ \\
\hline 5. & $\begin{array}{l}\text { Outfit z-standard (ZSTD) } \\
\text { value }\end{array}$ & $-2.0<$ ZSTD $>2.0$ \\
\hline 6. & $\begin{array}{l}\text { Standardized Residual } \\
\text { Correlation Value }\end{array}$ & $>0.70$ \\
\hline
\end{tabular}

Firstly, check result of analysis reliability of respondents and items show that, if reliability index is greater than 0.80 , mean very good and received strongly, but if the approximate value of 0.8 is also calculated at a good and strong [38] and for separation index if greater than 2.0, mean have very good isolation index value and able to continuous in actual study, but if the approximate value of 2.0 is also good condition and acceptable [37]. The result analysis reliability of respondents (person) showed that reliability index is 0.99 in which is very good and high acceptable and the separation index is 8.66 also showed very good result and that mean good to continuous. The Table III shows the analysis reliability of respondents (person) for this pilot study.

Table III: Analysis Reliability of Respondents (Person)

\begin{tabular}{|c|c|}
\hline Person Reliability & Person Separation \\
\hline 0.99 & 8.66 \\
\hline
\end{tabular}

While, the result of analysis reliability of items showed that reliability index is 0.72 in which is good condition and acceptable and the separation index is 1.62, if rounded off equal to 2.00 it also showed good result and able to continuous in actual study. The Table IV shows the analysis reliability of items for this pilot study. 
Table IV: Analysis Reliability of Items

\begin{tabular}{|c|c|}
\hline Item Reliability & Item Separation \\
\hline 0.72 & 1.62 \\
\hline
\end{tabular}

\section{Polarity Items of PTMEA CORR Value}

The examination of polarity items of Point Measure Correlation (PTMEA CORR) value is to determine the validity of the items produced in measuring the effectiveness of an element to be measured. This is to detect the polarity items which to test how far that item to achieve the goal of study. According to [37] if the value found in the PTMEA CORR is the positive $(+)$, it show the items can measure the constructs that want to measured, but if the value found in the PTMEA CORR is the negative (-), it show the items does not to measure the constructs and needs to repaired or dropped. Based on Table V showing have 12 items that negative value in the PTMEA CORR namely; PMS3 (-0.51), AW5 (-0.52), IN3 (-0.55), MM2 (-0.55), AW4 (-0.60), PS3 (-0.62), AW6 $(-0.65)$, MKT3 (-0.65), MM1 (-0.67), MKT1 (-0.68), TD2 $(-0.69)$ and ISK2 (-0.71). While the other rest items show the value of PTMEA CORR is positive. After discuss with expert of instrument the researcher decide, the finding result shows 12 items should be dropped and the other rest items is able to moving on direction of construct to being measured [37]. The code of item is referring to elements of this study. That element is none provided in this study.

Table V: Point Measure Correlation Value

\begin{tabular}{|c|c|c|c|c|c|}
\hline $\begin{array}{c}\text { Entry } \\
\text { Number }\end{array}$ & $\begin{array}{c}\text { Point } \\
\text { Measure } \\
\text { Corr. }\end{array}$ & Item & $\begin{array}{c}\text { Entry } \\
\text { Number }\end{array}$ & $\begin{array}{c}\text { Point } \\
\text { Measure } \\
\text { Corr. }\end{array}$ & Item \\
\hline 26 & 0.33 & PMS2 & 46 & 0.65 & PF1 \\
\hline 4 & 0.34 & IN1 & 45 & 0.65 & TE3 \\
\hline 25 & 0.42 & PMS1 & 119 & 0.66 & DA2 \\
\hline 31 & 0.44 & MSF1 & 107 & 0.66 & KAT2 \\
\hline 11 & 0.44 & AW2 & 47 & 0.66 & PF2 \\
\hline 43 & 0.46 & TE1 & 37 & 0.66 & PDT1 \\
\hline 10 & 0.46 & AW1 & 28 & -0.67 & MM1 \\
\hline 32 & 0.47 & MSF2 & 79 & 0.67 & PK1 \\
\hline 128 & 0.48 & IAI2 & 108 & 0.67 & KAT3 \\
\hline 95 & 0.48 & PJP2 & 73 & 0.67 & KIK1 \\
\hline 59 & 0.48 & KDI2 & 74 & 0.67 & KIK2 \\
\hline 12 & 0.50 & AW3 & 127 & 0.68 & IAI1 \\
\hline 44 & 0.51 & TE2 & 139 & 0.68 & PSP1 \\
\hline 27 & -0.51 & PMS3 & 36 & 0.68 & PBF3 \\
\hline 14 & -0.52 & AW5 & 76 & -0.68 & MKT1 \\
\hline 5 & 0.52 & IN2 & 64 & 0.68 & ME1 \\
\hline 49 & 0.52 & MK1 & 109 & 0.68 & TGM1 \\
\hline 122 & 0.53 & RGA2 & 116 & -0.69 & TD2 \\
\hline 102 & 0.53 & HOA3 & 104 & 0.69 & US2 \\
\hline 53 & 0.54 & PBP2 & 48 & 0.69 & PF3 \\
\hline 22 & 0.54 & PS1 & 99 & 0.69 & ATK3 \\
\hline 6 & -0.55 & IN3 & 34 & 0.69 & PBF1 \\
\hline 29 & -0.55 & MM2 & 130 & 0.70 & PTT1 \\
\hline 18 & 0.55 & IoT3 & 93 & 0.70 & PDR3 \\
\hline 121 & 0.56 & RGA1 & 19 & 0.70 & PBW1 \\
\hline 123 & 0.56 & RGA3 & 72 & 0.70 & ATP3 \\
\hline 137 & 0.57 & PIW2 & 17 & 0.70 & IoT2 \\
\hline 62 & 0.58 & TDK2 & 35 & 0.70 & PBF2 \\
\hline 70 & 0.58 & ATP1 & 8 & 0.70 & TM2 \\
\hline 58 & 0.58 & KDI1 & 117 & 0.71 & TD3 \\
\hline
\end{tabular}

\begin{tabular}{|c|c|c|c|c|c|}
\hline 132 & 0.58 & PTT3 & 125 & 0.71 & PMP2 \\
\hline 94 & 0.58 & PJP1 & 68 & -0.71 & ISK2 \\
\hline 55 & 0.58 & KP1 & 133 & 0.71 & PRT1 \\
\hline 97 & 0.59 & ATK1 & 120 & 0.71 & DA3 \\
\hline 134 & 0.59 & PRT2 & 16 & 0.71 & IoT1 \\
\hline 41 & 0.59 & MST2 & 115 & 0.71 & TD1 \\
\hline 75 & 0.60 & KIK3 & 91 & 0.71 & PDR1 \\
\hline 13 & -0.60 & AW4 & 111 & 0.72 & TGM3 \\
\hline 9 & 0.60 & TM3 & 118 & 0.72 & DA1 \\
\hline 101 & 0.60 & HOA2 & 110 & 0.73 & TGM2 \\
\hline 89 & 0.60 & AKT2 & 85 & 0.73 & AS1 \\
\hline 114 & 0.60 & PIP3 & 82 & 0.73 & PPP1 \\
\hline 124 & 0.61 & PMP1 & 1 & 0.73 & TK1 \\
\hline 54 & 0.62 & PBP3 & 87 & 0.73 & AS3 \\
\hline 23 & 0.62 & PS2 & 71 & 0.73 & ATP2 \\
\hline 39 & 0.62 & PDT3 & 65 & 0.74 & ME2 \\
\hline 103 & 0.62 & US1 & 69 & 0.74 & ISK3 \\
\hline 96 & 0.62 & PJP3 & 61 & 0.74 & TDK1 \\
\hline 135 & 0.62 & PRT3 & 30 & 0.74 & MM3 \\
\hline 24 & -0.62 & PS3 & 38 & 0.74 & PDT2 \\
\hline 7 & 0.62 & TM1 & 84 & 0.75 & PPP3 \\
\hline 42 & 0.63 & MST3 & 77 & 0.75 & MKT2 \\
\hline 3 & 0.63 & TK3 & 136 & 0.75 & PIW1 \\
\hline 60 & 0.64 & KDI3 & 63 & 0.75 & TDK3 \\
\hline 52 & 0.64 & PBP1 & 66 & 0.75 & ME3 \\
\hline 90 & 0.64 & AKT3 & 131 & 0.76 & PTT2 \\
\hline 106 & 0.64 & KAT1 & 57 & 0.76 & KP3 \\
\hline 100 & 0.64 & HOA1 & 140 & 0.76 & PSP2 \\
\hline 105 & 0.64 & US3 & 40 & 0.77 & MST1 \\
\hline 2 & 0.64 & TK2 & 80 & 0.77 & PK2 \\
\hline 33 & 0.64 & MSF3 & 20 & 0.77 & PBW2 \\
\hline 88 & 0.64 & AKT1 & 92 & 0.79 & PDR2 \\
\hline 129 & 0.64 & IAI3 & 98 & 0.79 & ATK2 \\
\hline 51 & 0.65 & MK3 & 113 & 0.79 & PIP2 \\
\hline 112 & 0.65 & PIP1 & 141 & 0.79 & PSP3 \\
\hline 67 & 0.65 & ISK1 & 126 & 0.80 & PMP3 \\
\hline 50 & 0.65 & MK2 & 86 & 0.80 & $\mathrm{AS} 2$ \\
\hline 15 & -0.65 & AW6 & 138 & 0.82 & PIW3 \\
\hline 21 & 0.65 & PBW3 & 81 & 0.82 & PK3 \\
\hline 78 & -0.65 & MKT3 & 83 & 0.83 & PPP2 \\
\hline 56 & 0.65 & KP2 & & & \\
\hline
\end{tabular}

\section{Item Fit Measure Construct}

The examination of the item fit measure construct is to measure the constructs that can be seen from the value of index Mean-Square (MNSQ) Outfit. The value of Index MNSQ Outfit should be in range between to 0.60 to 1.40 and if other than that items need to considerate to dropped or repaired [37]. This is to ensure that the items used are appropriate in measuring the constructs of the study. That item need to follow two conditions, namely (i) if value of MNSQ Outfit smaller than 0.60 , it mean items is too easy to expect by the respondent; and (ii) if greater than 1.40, it mean items is confusing and misleading to answer by respondent. Besides that, the index Standardized $\mathrm{Z}$ Values (ZSTD) value also should be -2 to +2 , but if the MNSQ Outfit value be accepted, the ZSTD value can be ignored in this study.

Because of that, if two conditions not fulfill, then the items needs to be considered for dropped or repaired. The Table VI shows, 6 items are smaller than 0.60 of MNSQ Outfit value and 14 items is greater than 1.40 of MNSQ Outfit value. That means the 20 items need dropped 
from questionnaire. This decision is also referring to discussion with expert to ensure the items dropped not able impact the result of actual study. According to finding, there are 20 items that are not in the specified range and need dropped from the instrument survey. There are some items less than the value of 0.60 in MNSQ outfit are MM3 (0.56), PS2 (0.55), MKT2 (0.57), TK1 (0.55), PTT2 (0.58) and PMP3 (0.55) and the other is above the value of 1.40 in MNSQ outfit are AW3 (1.47), TK2 (1.86), TE1 (1.63), AW2 (1.52), PIP3 (1.49), PMS2 (1.42), IN2 (1.48), PMS1 (1.42), AW1 (1.49), MSF1 (1.46), IAI2 (1.43), IN1 (1.43), PS1 (1.42) and TK3 (1.48). This diagnosis shows that the 20 items were dropped according to the needs of researchers and expert views.

Table VI: Item fit based on MNSQ Outfit Value

\begin{tabular}{|c|c|c|c|c|c|}
\hline \multirow{2}{*}{$\begin{array}{c}\text { Entry } \\
\text { Numbe } \\
\mathbf{r}\end{array}$} & \multicolumn{2}{|c|}{ Infit } & \multicolumn{2}{c|}{ Outfit } & \multirow{2}{*}{ Items } \\
\cline { 2 - 5 } & MNSQ & ZSTD & MNSQ & ZSTD & \\
\hline 12 & 1.90 & 3.0 & 1.47 & 1.6 & AW3 \\
\hline 2 & 1.83 & 3.2 & 1.86 & 3.3 & TK2 \\
\hline 43 & 1.61 & 2.3 & 1.63 & 2.5 & TE1 \\
\hline 11 & 1.58 & 2.2 & 1.52 & 2.0 & AW2 \\
\hline 114 & 1.46 & 1.9 & 1.49 & 1.9 & PIP3 \\
\hline 26 & 1.48 & 2.0 & 1.42 & 1.8 & PMS2 \\
\hline 5 & 1.48 & 1.8 & 1.48 & 1.3 & IN2 \\
\hline 25 & 1.48 & 2.0 & 1.42 & 1.8 & PMS1 \\
\hline 10 & 1.48 & 1.8 & 1.49 & 1.4 & AW1 \\
\hline 31 & 1.32 & 1.3 & 1.46 & 1.8 & MSF1 \\
\hline 128 & 1.13 & 0.6 & 1.43 & 1.7 & IAI2 \\
\hline 4 & 1.34 & 1.2 & 1.43 & 0.8 & IN1 \\
\hline 22 & 1.32 & 1.4 & 1.42 & 1.4 & PS1 \\
\hline 3 & 1.14 & 0.7 & 1.48 & 1.2 & TK3 \\
\hline 30 & .78 & -1.0 & 0.56 & -0.6 & MM3 \\
\hline 23 & .78 & -1.0 & 0.55 & -0.7 & PS2 \\
\hline 77 & .84 & -0.7 & 0.57 & -1.0 & MKT2 \\
\hline 1 & .81 & -0.8 & 0.55 & -1.1 & TK1 \\
\hline 131 & .58 & -.2 .2 & 0.58 & -2.2 & PTT2 \\
\hline 126 & .56 & -2.2 & 0.55 & -2.2 & PMP3 \\
\hline & & & & & \\
\hline
\end{tabular}

\section{E. Measurement of Standardized Residual Correlation} Value

The analysis of standardized residual correlation value is to determine whether the items have similarly meaning and overlap with other items. Referring to Table VII shows have 2 pairs of items of standardized residual correlation value is above 0.70 . According that result, one of items in pairs need to dropped because the item is likely similar or both items is share same purpose. Based on [38], if the correlation value of the two items exceeds 0.70 , this indicates the value of correlation is high and only one items to be used in measuring the constructs in this study.

According to the finding there are two pairs of items; (i) TD1 pair with TD2) and; (ii) PMS1 pair with PMS2. For find the final result, need to see the MNSQ Outfit of items is pairs and the smaller value need dropped. The first pairs item of TD1 (0.86) and TD2 (0.82), show that the TD2 (0.82) is need to dropped because TD1 (0.86) of MNSQ Outfit value is higher. Then, second pairs items of PMS1 (1.42) pair with PMS2 (1.42) have same MNSQ Outfit value that mean both items need dropped, but actually in item fit measure construct

examination that items is done dropped, that mean both of items is automatically removed in this questionnaire.

Table VII. Standardized Residual Correlation value

\begin{tabular}{|l|l|l|l|l|}
\hline $\begin{array}{l}\text { Correlatio } \\
\text { n }\end{array}$ & $\begin{array}{l}\text { Entry } \\
\text { Number }\end{array}$ & Items & $\begin{array}{l}\text { MNS } \\
\mathbf{Q} \\
\text { Outfit }\end{array}$ & Result \\
\hline \multirow{2}{*}{0.78} & 115 & TD1 & 0.86 & $\begin{array}{l}\text { Retaine } \\
\text { d }\end{array}$ \\
\cline { 2 - 5 } & 116 & TD2 & 0.82 & Remove \\
\hline \multirow{2}{*}{0.74} & 25 & PMS1 & 1.42 & Remove \\
\cline { 2 - 5 } & 26 & PMS2 & 1.42 & Remove \\
\hline
\end{tabular}

\section{F. Finding of Items in Pilot Study}

After the entire functionality checker from Rasch measurement model examination, summary of final result for pilot study is shows in Table VIII. Based on the pilot test result 32 items not meet requirement of analysis and need to remove from questionnaire. But this decision still referring to expert considers supporting this finding. The finding of the pilot study have obtained 109 items for 39 elements that can be used and 32 items for 7 elements that need to be delete when analysis is done.

Table VIII. Summary Final Result of Items Survey

\begin{tabular}{|c|c|c|c|c|}
\hline Domain & Retain Item & $\begin{array}{c}\text { Total } \\
\text { Reta } \\
\text { in } \\
\text { Item }\end{array}$ & $\begin{array}{l}\text { Remove } \\
\text { Item }\end{array}$ & $\begin{array}{c}\text { Total } \\
\text { Rem } \\
\text { ove } \\
\text { Item }\end{array}$ \\
\hline $\begin{array}{l}\text { Collaborat } \\
\text { ive } \\
\text { Learning } \\
\text { (CL) }\end{array}$ & $\begin{array}{l}\text { TDK1,TDK2,TD } \\
\text { K3,ME1,ME2,M } \\
\text { E3,ISK1,ISK3,A } \\
\text { TP1,ATP2,ATP3, } \\
\text { KIK1,KIK2,KIK3 } \\
\text {,PK1,PK2,PK3,P } \\
\text { PP1,PPP2 \& } \\
\text { PPP3 }\end{array}$ & 20 & $\begin{array}{l}\text { ISK2,MK } \\
\text { T1,MKT2 } \\
\& \text { MKT3 }\end{array}$ & 4 \\
\hline $\begin{array}{l}\text { Practical } \\
\text { Learning } \\
\quad(\mathrm{PL})\end{array}$ & $\begin{array}{l}\text { AS11,AS2,AS3,A } \\
\text { KT1,AKT2,AKT } \\
\text { 3,PDR1,PDR2,P } \\
\text { DR3,PJP1,PJP2,P } \\
\text { JP3,ATK1,ATK2 } \\
\text {,ATK3,HOA1,H } \\
\text { OA2,HOA3,US1, } \\
\text { US2,US3,KAT1, } \\
\text { KAT2,KAT3 }\end{array}$ & 24 & - & 0 \\
\hline $\begin{array}{c}\text { Interactive } \\
\text { Learning } \\
\text { (IL) }\end{array}$ & $\begin{array}{l}\text { TGM1,TGM2,T } \\
\text { GM3,PIP1,PIP2, } \\
\text { TD1,TD3,DA1,D } \\
\text { A2,DA3,RGA1,R } \\
\text { GA2,RGA3,PMP } \\
\text { 1,PMP2,IAI1,IAI } \\
\text { 3,PTT1,PTT3,PR } \\
\text { T1,PRT2,PRT3,P } \\
\text { IW1,PIW2,PIW3, } \\
\text { PSP1,PSP2 \& } \\
\text { PSP3 }\end{array}$ & 28 & $\begin{array}{l}\text { PIP3,TD2, } \\
\text { PMP3,IAI } \\
2 \text { \& PTT2 }\end{array}$ & 5 \\
\hline Total & & 109 & & 32 \\
\hline
\end{tabular}




\begin{tabular}{|c|c|c|c|c|}
\hline $\begin{array}{c}\text { Domai } \\
\text { n }\end{array}$ & Retain Item & $\begin{array}{c}\text { Total } \\
\text { Reta } \\
\text { in } \\
\text { Item }\end{array}$ & Remove Item & $\begin{array}{c}\text { Total } \\
\text { Remo } \\
\text { ve } \\
\text { Item }\end{array}$ \\
\hline $\begin{array}{c}\text { Online } \\
\text { Learni } \\
\text { ng } \\
(\mathrm{OL})\end{array}$ & $\begin{array}{l}\text { TM1,TM2,TM3,I } \\
\text { oT1,IoT2,IoT3,P } \\
\text { BW1,PBW2,PB } \\
\text { W3,MSF2,MSF3, } \\
\text { PBF1,PBF2 \& } \\
\text { PBF3 }\end{array}$ & 14 & $\begin{array}{l}\text { TK1,TK2,TK } \\
\text { 3,IN1,IN2,IN } \\
\text { 3,AW1,AW2, } \\
\text { AW3,AW4,A } \\
\text { W5,AW6,PS1 } \\
\text {,PS2,PS3,PM } \\
\text { S1,PMS2,PM } \\
\text { S3,MM1,MM } \\
\text { 2, MM3 \& } \\
\text { MSF1 }\end{array}$ & 22 \\
\hline $\begin{array}{l}\text { Blende } \\
\text { d } \\
\text { Learni } \\
\text { ng } \\
(\mathrm{BL})\end{array}$ & $\begin{array}{l}\text { PDT1,PDT2,PDT } \\
\text { 3,MST1,MST2, } \\
\text { MST3,TE2,TE3, } \\
\text { PF1,PF2,PF3,MK } \\
\text { 1,MK2,MK3,PB } \\
\text { P1,PBP2,PBP3,K } \\
\text { P1,KP2,KP3,KDI } \\
\text { 1,KDI2 \& KDI3 }\end{array}$ & 23 & TE1 & 1 \\
\hline
\end{tabular}

According the finding that can conclude the validity and reliability of instrument is important procedure to create new items in questionnaire. Researcher need to consider this procedure of pilot test is very important to measure the reliability of new items and respondent test to answer that item. Referring to [37], the advantage of using Rasch Measurement Model is able to identify the fitness, difficulty level and problematic scan of items and respondent in pilot study. The new item should be do pilot test to ensure that items can be used in researcher correctly. Thus, that ways can be improve the items validity and reliability to ensure each constructs is acceptable to fulfill research question.

\section{Discussion AND Conclusion}

In this study, the validity and reliability of the test instrument were reinforced by the Rasch measurement model. Overall, show that reliability and separated person and item is in good and accepted in this study. Then the polarity items of PTMEA CORR value, item fit based on MNSQ value and measurement of standardized residual correlation value is shows 32 items of 7 elements need to remove from the questionnaire. That means 109 items of 39 elements for Technology Enabled/Enhanced Active Learning (TEAL) is ability to measure the understanding of learning and built job-related skills among students in civil engineering fields. The beneficial of using Rasch measurement model is able to illustrate the construct of validate item clearly and reliable and legitimate to measure student perspective in active learning surrounding using technology tools. After data analysis, the validity and reliability of each item in this pilot study is important to ensure data is accurate with research. Data finding is to test the item in questionnaire is able to use in actual study. To conclude, the findings of this study, the pilot test were able to accommodate of research design in survey. That mean terms of suitability of items in questionnaire is can be conform of construct to the research question. This is to enhance the quality of instruments development when measuring the domains and elements of TEAL.

\section{ACKNOWLEDGMENT}

The author would like to thank to Malaysian Ministry of Higher Education and Universiti Tun Hussein Onn Malaysia (UTHM) for supporting this research under the scholarship of the Ministry of Higher Education (Mybrain 15).

\section{REFERENCES}

[1] Zhou, K., Liu, T., \& Zhou, L. (2015). Industry 4.0: Towards future industrial opportunities and challenges. In Fuzzy Systems and Knowledge Discovery (FSKD), 2015 12th International Conference on (pp. 2147-2152). IEEE

[2] Hassan, N. F., Puteh, S., \& Buhari, R. (2015). Student understanding through the application of technology enabled Active Learning in practical training. Procedia-Social and Behavioral Sciences, 204, 318-325.

[3] Drake, E., \& Battaglia, D. (2014). Teaching and learning in active learning classrooms. The Faculty Center for Innovative Teaching: Central Michigan University.

[4] Hassan, N. F., \& Puteh, S. (2017). A Survey of Technology Enabled Active Learning in Teaching and Learning Practices to Enhance the Quality of Engineering Students. Advanced Science Letters, 23(2), 1104-1108.

[5] Tsai, C. W., Lai, C. F., Chiang, M. C., \& Yang, L. T. (2014). Data mining for Internet of Things: A survey. IEEE Communications Surveys and Tutorials, 16(1), 77-97

[6] Abdullah, Z., Ramlan, M.F., \& Sabran, M.S., (2014). Developing A Student Development Index: A Conceptual Paper.

[7] Hassan, N. F., Puteh, S., \& Sanusi, A. (2019). Fleiss's Kappa: Assessing the Concept of Technology Enabled Active Learning (TEAL). Journal of Technical Education and Training, 11(1). Journal of Technical Education and Training Vol. 11 No. 1 (2019) p. 109-118.

[8] Hamilton Smith TEAL Classrooms, (2017). Technology Enabled Active Learning (TEAL) Classroom. www.unh.edu.

[9] Wiersma, W., (2000). Research methods in education: An introduction (7th ed.).Boston: Allyn \& Bacon.

[10] Parmjit, S., Chan,Y. F., Gurnam, K. S,.\& Ranjit, K. (2010). Panduan Komprehensif Penulisan Cadangan Penyelidikan. Shah Alam: Pusat Penerbitan Universiti (UPENA) UiTM.

[11] Johanson, G. A. \& Brooks, G. P. 2010. Initial Scale Development: Sample Size for Pilot Studies. Educational and Psychological Measurement 70(3): 394-400.

[12] Aziz, A. (2010). Anthelmintic Resistance, Validation of FAMACHA and Effects of Management Practices in Selected Goat Farms in Terengganu, Malaysia. Universiti Putra Malaysia.

[13] Wright, B. \& Stone, M. H. (1979). Best Test Design. Rasch Measurement. Chicago: MESA Press.

[14] Dori, Y.J., \& Belcher.W.J, (2005). How Does Technology Enabled Active Learning Affect Undergraduate Students' Understanding of Electromagnetism Concepts?. The Journal of The Learning Sciences, 14 (2). 243-279.

[15] Shieh, R.S., Chang, W., \& Tang, J., (2010). The Impact Of Implementing Technology- Enabled Active Learning (TEAL) In University Physics In Taiwan. The Asia-Pacific Education Researcher, 19 (3). 401-415.

[16] Morrison, J. L. and Long, P.,(2009).The iCampus Technology-Enabled Active Learning Project at MIT: An Interview with Phillip Long ," Innovate: Journal of Online Education: Vol. 5: Iss. 4, Article 1.

[17] Cinganotto, L., Panzavolta, S., Garista, P., Guasti, L., \& Dourmashkin, P. (2016). TEAL as an innovative teaching model Insights from "Educational Avant-Garde" Movement in Italy. Journal of e-Learning and Knowledge Society, 12(2).

[18] Belcher, J. (2005).Technology enabled active learning: Retrieved on May $5,2018$.

[19] Dourmashkin, C. R. (2010). Bridging the Gap: How Interactive Mapping Can Facilitate Public Participation in a Wired Community (Doctoral dissertation, Columbia University).

[20] Ostermeier,C., Prenzel, M., \& Duit, R., (2010). Improving Science and Mathematics Instruction: The SINUS Project As An Example for Reform as Teacher Professional Development. International Journal of Science Education, 32(3). 303-327.

[21] Pirker, J. (2013). The Virtual TEAL World-An Interactive and Collaborative Virtual World Environment for Physics Education (Doctoral dissertation, Master's thesis, Graz University of Technology).

[22] Chiu, P. H. P. (2016). A technology-enriched active learning space for a new gateway education programme in Hong Kong: A platform for nurturing student innovations. Journal of Learning Spaces, 5(1). 
[23] Hassan, N. F., Puteh, S., \& Sanusi, A. (2018). Elements of Technology Enabled/Enhanced Active Learning (TEAL) to Enhance Quality and Employability of Bachelor's Students. In MATEC Web of Conferences (Vol. 150, p. 05005). EDP Sciences.

[24] Foote, K. T. (2014). Factors Underlying the Adoption and Adaption of a University Physics Reform over Three Generations of Implementation. Electronic Journal of Science Education, 18(3).

[25] Peberdy, D., \& Consultancy, D. N., (2014). The Case for Active Learning Environments in University Education. Droitwich Net.

[26] Breslow, L., (2010). Wrestling With Pedagogical Change: The TEAL Initiative at MIT Change. The Magazine of Higher Learning, 42 (5). 23-29.

[27] Peberdy, D., (2014) Active Learning Spaces and Technology. Advances in Higher \& Further Education (DroitwichNet)

[28] Parishan, N., Jafari, E.M., \& Fatemehnosrat (2011). The Effect of Technology Enabled Active Learning (TEAL) Method in Biology on The Academic Achievements of Students. Procedia - Social And Behavioral Sciences, World Conference On Educational Technology Researches, 28 (1). 542-546

[29] Long, T., Logan, J., Cummins, J., \& Waugh, M. (2016). Students' and Instructor's Attitudes and Receptions of the Viability of Using A Flipped Classroom Instructional Model In A Technology-Enabled Active Learning (TEAL) Classroom. Journal of Teaching and Learning with Technology, 5(1), 46. https://doi.org/10.14434/jotlt.v5n1.18879.

[30] Chida, M., \& Brown, G., (2011). Evaluating The Gap Between Industry Assessment of Job Readiness and Graduation Standards in Higher Education Institutions: The Case of Fashion Studies. International Journal of Fashion Design Technology and Education, 4(2). 71-82.

[31] Schuster, K., Groß, K., Vossen, R., Richert, A., \& Jeschke, S. (2016). Preparing for industry 4.0-collaborative virtual learning environments in engineering education. In Engineering Education 4.0 (pp. 477-487). Springer, Cham.

[32] Clark, V. P., \& Creswell, J. W. (2011). Designing and conducting mixed methods research. Retrieved on July, 25, 2016.

[33] Wiersman, W., \& Jurs, S. G. (2009). Research methods in education: An introduction.

[34] Abdul Ghafar, M. N., (2003). Reka Bentuk: Soal Selidik Pendidik. Skudai: Universiti Teknologi Malaysia.

[35] Creswell, J.W., (2009). Research Design: Qualitative, Quantitative, and Mixed Methods Approaches. 3rd Edition. Los Angeles: Sage Publications, Inc., 2009.

[36] Rasch, G. (1980). Probabilistic Models for Some Intelligence And Attainment Test. Chicago, IL: University of Chicago Press.

[37] Bond, T. G., \& Fox, C. M. (2007). Applying the Rasch model: Fundamental measurement in the human sciences. (2nd ed.) Lawrence Erlbaum Associates, Publisher. Mahwah, New Jersey, London.

[38] Linacre, J.M., (2005). A user's guide to WINSTEPS: Rasch- model computer program. Chicago: MESA Press.

\section{AUTHORS PROFILE}

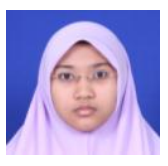

Nur Farha bte Hassan, received the B.S. degree in Electrical Engineering from Universiti Tun Hussein Onn Malaysia in 2015, where she is currently pursuing the Ph.D. degree in Technical and Vocational Education. Her current research interests include Technology Enabled Active Learning.

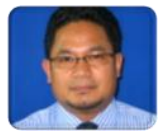

Saifullizam bin Puteh, received the B.S. degree in Electrical Engineering from Universiti Teknologi Malaysia in 1998 and the Ph.D. degree in Computational Intelligent in Nottingham Trent University in 2014. He is currently an Associate Professor with the Universiti Tun Hussein Onn Malaysia in Faculty Technical and Vocational Education. His current research interests include innovation and technology in TVET, Computational Intelligent, Electronic and Electrical Engineering, Occupational Work and Competence Development, Shaping Work and Technology.

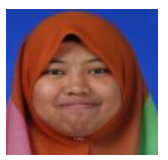

Amanina binti Muhamad Sanusi, received the B.S. degree in Electrical Engineeing from Universiti Tun Hussein Onn Malaysia in 2015, where she is currently pursuing the Ph.D. degree in Technical and Vocational Education. Her current research interests include talents and workability in education.

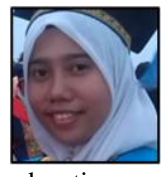

Nor Hartini Binti Che Mohamad Zahid, received the B.S degree in Electrical Engineering from Universiti Tun Hussein Onn Malaysia in 2009, where she is currently pursuing the Ph.D. degree in Technical and Vocational Education. Her current research interests include rubric assessment in 